\author{
Dariusz Pyza \\ Dr hab. inż., prof. PW \\ Wydział Transportu, Politechnika \\ Warszawska \\ dpz@wt.pw.edu.pl
}

DOI: 10.35117/A_ENG_19_04_01

\title{
Transport technologies in intermodal transport
}

\begin{abstract}
The issue of intermodal transport is an important matter for the integration of transport between different modes of transport. The specificity of intermodal transport loading units requires the search for innovative transport technologies to make transport more efficient. The article presents the systematics of knowledge in the field of intermodal transport and transport systems determined by the type of intermodal loading unit. In addition, the transhipment terminal, which plays an essential role in intermodal transport in the integration of different modes of transport, has been characterized. Technical and technological characteristics of selected innovative transport systems in intermodal transport, determined by the type of intermodal loading units, are also presented. The comparison of these systems was made with regard to technical and economic parameters.
\end{abstract}

Keywords: Intermodal transport; Transport technologies; Intermodal terminals

\section{Introduction}

The economic development of the European Union (EU) countries determines the development of transport, which affects the improvement of economic systems and creates the possibility of moving from solutions based on the use of resources in the vicinity of the places of their production and consumption to solutions based on specialization to the greatest extent possible, i.e. the progressive international division of labour. This phenomenon makes the movement of goods in economic systems increasingly complex and technologically advanced, and supply chains increasingly extensive, extending to larger regions. In supply chains, transport is essential to ensure the most efficient, under given conditions and effective flow of raw materials, semi-finished and finished products from the places of their dispatch shipment to the places of their receipt - destination[8], [21],[26], [28], [[30], [31], [33].

The specificity of supply chains, determined by the type of cargo and its susceptibility, influences the organization of transport and the transport technology used.

Systematically growing cargo flows in economic systems imply an increase in the importance of sustainable transport. Such an approach requires not only efficient use of the transport capacity of the various modes of transport, but also the search for alternative, environmentally friendly sources of propulsion. In the field of freight transport, there are high expectations for the development of high-speed rail transport, including intermodal transport. It should be noted that in many cases these expectations are divergent, between different stakeholders in the intermodal transport market, which include: infrastructure managers and representatives of carriers, operators of intermodal terminals, companies using transport services - shippers and recipients of cargo as well as representatives of environmental entities, e.g. public administration entities or shippers at other trans-shipment terminals [4], [8], [23], [[27], [29], [39]. Planning and forecasting of future transport needs, intermodal transport networks and transports themselves is an essential element of sustainable transport. Therefore, in order for freight transport to be efficient, a multidisciplinary, integrated transport network 
based on a modern and well-designed infrastructure is needed. This applies in particular to technical, organisational and commercial aspects [8], [31].

Transport and its dynamic development entails both environmental and social costs. Moreover, it has a negative impact on the natural environment, causing high external costs of transport, such as: emission of harmful exhaust fumes, increased noise level, accident rate, etc. The scale and diversity of problems resulting from transport activity leads to an urgent reduction of its impact on the natural and social environment[1]. The most important of these should include measures such as improving the competitiveness of the railway sector and increasing the share of rail in the modal split, or developing intermodal transport, including support for the creation of intermodal terminals.

The intermodal transport segment in Poland is a young market characterized by small but constant development. An increase of this type of transport can be observed in comparison with the total of goods transport, but the share of intermodal transport work in freight transport in Poland is still relatively small - in 2018 it was at the level of $10.33 \%$. In countries where there is effective state aid for the development of environmentally friendly transport systems, the share of intermodal transport with the use of railways exceeds $30 \%$. The aim of the paper is to systematize the knowledge in the field of intermodal transport and transport systems used as well as to refer to selected technical and economic characteristics and construction of such systems.

\section{Intermodal transport and its specificity}

Its transport susceptibility is of fundamental importance for the selection of cargo transport technology. There are three types of susceptibility [5], [8]:

- natural susceptibility - resulting from the natural physical, chemical and biological characteristics and properties of the cargo, which determine its sensitivity to the intended effects of transport and its resistance to the conditions and effects of transport,

- technical susceptibility - resulting from the state of aggregation of the cargo as well as from external features and properties which determine the necessity to perform specific procedures to adapt the cargo for transport. These procedures affect the size (weight and space) and shape of the load, the type and durability (strength) of the packaging, as well as the type of working tools used,

- economic vulnerability - taking into account the possibility of transferring the value of the transport service to the value of the cargo at the place of its delivery or the social and economic necessity of the transport.

Considering the transport vulnerability of cargo and the cost and time of transport, it should be noted that one of the problems of modern transport systems is the proper assessment of the adjustment of transport organization and technology in relation to the needs reported by the purchasers of transport services.

In order to maintain the balance between different modes of transport and to limit the negative environmental effects of transport, the European Union (EU) has undertaken actions concerning, inter alia, support for the development of intermodal transport within the framework of the policy of sustainable development of transport in the EU[6], [8], [13], [18], [[31], which is written in the following table:

- The EU 2020 Strategy: A strategy for smart, sustainable and inclusive growth:

- promoting a resource-efficient, greener and more competitive economy,

- White Paper - Roadmap to a Single European Transport Area - Towards a competitive and resource efficient transport system:

- a $60 \%$ reduction in pollutant emissions in the transport sector by 2050 
- the use of rail transport for long-distance transport,

- Operational Programme Infrastructure and Environment 2014-2020 - transport objectives:

- development of sustainable and environmentally friendly transport,

- improving access to the European transport network.

The choice of the method of transporting cargo in the supply chains depends on its specificity and the transport technology used. Taking into account transport technologies, we distinguish multimodal, intermodal and combined technologies. These three terms have been interpreted in the European Economic Commission (UN/ECE), European Conference of Ministers of Transport (ECMT) and European Commission (EC) publication Combined Transport Terminology [6], [9], [31].

According to the above documents, multimodal transport is the transport of cargo through at least two different branches of transport, while the cargo may change the cargo unit. In intermodal transport, the transport of goods is carried out in one and the same transport unit or vehicle along the whole journey from consignor to consignee, using - consecutively - different modes of transport, without reloading the goods themselves. The intermodal mode of transport is combined transport, where the main part of the journey is made by rail, inland waterway or sea, and the initial and final sections by road, whereby the distance in the wagon zones should be as short as possible. Segment of initial or final carriage means carriage[8], [9], [[31], [38]

- between the point where the goods are loaded and the nearest appropriate rail loading station for the start section and between the nearest appropriate rail unloading station and the point where the goods are unloaded, for the end section or

- within a radius not exceeding $150 \mathrm{~km}$ in a straight line from an inland or maritime port of loading or unloading.

The use of intermodal technologies in transport systems and their specific features, based on the integration of different modes of transport allows to reduce the costs of the transport process and increase its efficiency, and at the same time allows to prepare a lower-price offer for the customer. It is also possible to organise transport in a variety of ways and to improve the quality of services by making deliveries faster, improving access to transport services and simplifying the procedures for moving goods and taking over the organisation, implementation and management of transport processes by an intermodal transport operator.

In combined transport there is an internal integration of transport processes on the planes[31]:

- technical and technological, including the adaptation of line and point infrastructure and means of transport of various branches, as well as transshipment facilities and machinery to handle intermodal loading units,

- organizational, consisting in the presence of specialized entities performing the functions of operators involved in the implementation of complex transport processes and one transport document along the entire delivery route,

- functional - in point infrastructure elements (intermodal terminals) there is an integration of functional areas of the terminal such as unloading, storage and loading zones for handling intermodal loading units.

Intermodal transport unit - UTI (Unités de Transport Intermodal) is a large container with parameters in accordance with PN ISO 668:2018-05, exchangeable body with parameters in accordance with UIC Charter No. 592-4, transport container in accordance with UIC Charter No. 591, semi-trailer adapted for intermodal transport in accordance with UIC Charter No. 
596-5, as well as a semi-trailer of bimodal system[9]. For the purpose of dimensioning the transported volumes, the term TEU (Twenty-feet Equivalent Unit) is also used, which is the unit of measure corresponding to the capacity of one 20-foot container.

The specificity of intermodal transport units makes that the most common are road-rail transports carried out in different technologies, with the largest share of container transports.

The following basic transport systems are distinguished within intermodal transport[8], [9], [11], [[31]

- container system (commonly used for several dozen years),

- the rail-road system "on a ram" (ger. Huckepack, or eng. piggyback) - concerns swap bodies and semi-trailers transported on special wagons (container and pocket wagons, and in the past also on cradle and kangaroo wagons),

- mobile road system (ger. Rollende Landstrasse)- commonly known as RL or Ro-La and also included in the Huckepack system,

- ACTS (Abroll Container Transport System) - applies to the transport of transport containers by rail and road,

- bimodal system - applies to the transport of semi-trailers on special railway carriages.

The implementation of intermodal services requires close cooperation between different partners, including rail infrastructure managers, intermodal terminal managers and combined transport operators, who manage the entire transport process and can offer customers finished services[8], [9], [20], [22], [31]. All activities are connected with incurring significant costs by individual participants of the whole transport process, which implies various types of restrictions. On the one hand, these are the technical constraints of the transport network, financial, environmental, social, etc. constraints, and on the other hand, the different points of view of the different actors involved in the transport process, each of which seeks to maximise its own individual benefit[8], [9], [10], [19].

Intermodal transport brings together the strengths of different modes of transport and creates synergies in terms of increased transport efficiency and reduced external costs. As a result of technological progress, transport technology and the role of individual branches in the movement of goods are systematically developed. Customers who want to satisfy their transport needs have a choice of different forms and types of cargo transportation, including[8], [15],[20], [[24], [31]

- through the various modes of transport,

- by various forms of transport organisation,

- using different technologies,

- using different means of transport within a single mode of transport.

The dominant factor in assessing the usefulness of particular forms of transport and types of cargo transport, especially transport technologies, is the provision of comprehensive logistics services according to the needs reported by customers[7], [8].

\section{Transhipment terminals and their role in intermodal transport}

The specificity of the organisation of transport in intermodal transport causes that transhipment terminals, called intermodal terminals, are becoming increasingly important in the transport of cargo. Intermodal trans-shipment terminal is a spatial object connected with infrastructure and proper organization, enabling effective and efficient trans-shipment of handled intermodal cargo units between means of transport belonging to different modes of transport and performing operations on these units in connection with their storage and use[8], [9], [31]. 
Transhipment terminals are a basic point infrastructure in intermodal transport networks and are equipped with appropriate transhipment equipment and machines, enabling transhipment of intermodal units between different modes of transport and stationary service in the terminal. They are located in large seaports and important land distribution centres with access to rail, road, sea and inland waterway transport infrastructure[3], [9], [14], [31].

In intermodal transport networks there are transhipment terminals with different capacities, which have different functions and tasks (Fig. 1). The location of transhipment terminals in the transport network is a determining factor for the efficient and effective functioning of intermodal transport. The specificity of intermodal transport consisting in the handling of cargo in long-distance transport by rail, sea and inland waterway transport, with the simultaneous provision of service areas with small radii of local terminals operated by road transport, requires the organization of hierarchical multi-territory systems. Such systems are characterised by the existence of terminals of different importance and their role in the hierarchy. In multi-territory hierarchical systems, there are central, regional and local terminals, between which transports are carried out in an efficient way with a comprehensive and fast customer service.

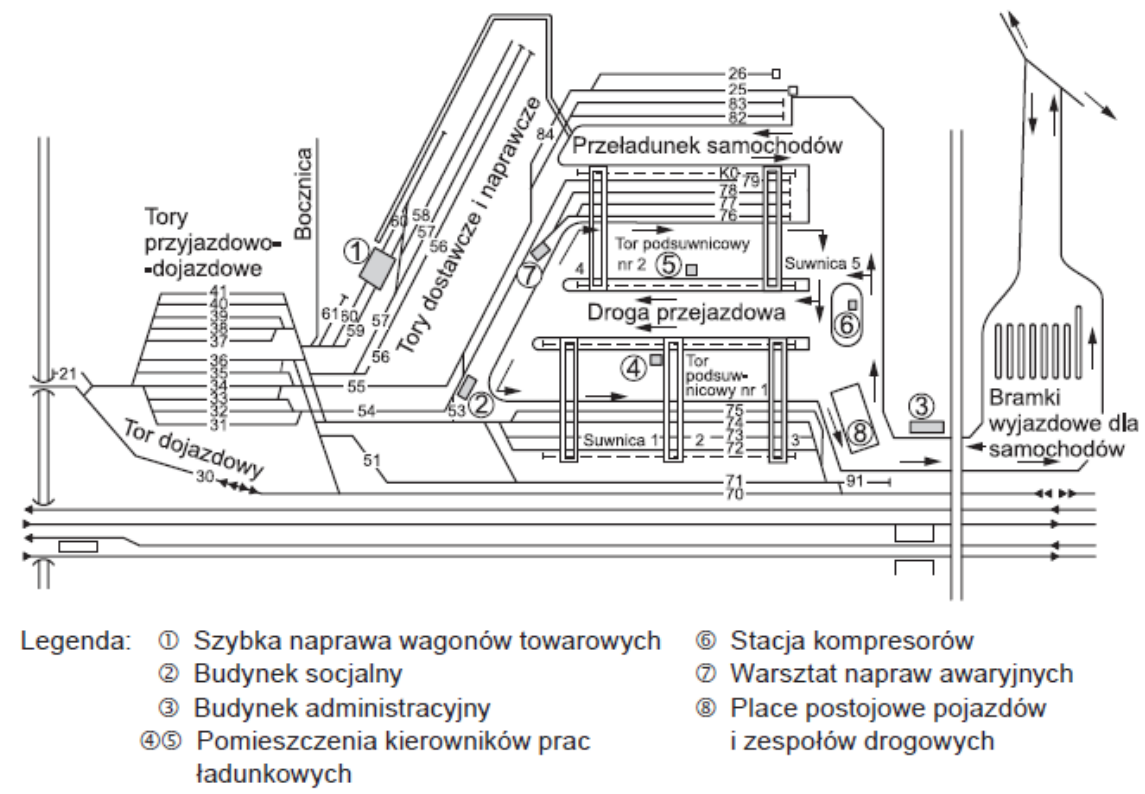

1. The diagram of examples of technical and technological solutions of the intermodal terminal. Source:[2], [8]

Technical and technological solutions of the intermodal trans-shipment terminal are determined by the number and type of cargo units and means of transport. In principle, technical and technological solutions of the terminal include[8], [11], [[31]:

- the track and road system of the terminal,

- storage and manipulation yards,

- Parking and parking lots and parking lots,

- cargo fronts, buildings and technical facilities.

The handling capacity of an intermodal terminal is determined by the handling capacity of the means of transport, the storage capacity of the intermodal loading units and the handling capacity of the machinery and equipment. Minimum requirements for intermodal transhipment terminals are regulated by the Agreement on major international combined transport lines and associated facilities (AGTC). The contract shall specify the required parameters for the infrastructure of lines and railway terminals. Guidelines in this respect are 
being prepared by the International Union of Railways (UIC). Selected technical parameters of railway infrastructure valid on AGTC lines are presented in Table $\mathbf{1 .}$

Tab. 1. Technical parameters of railway infrastructure valid on AGTC lines

\begin{tabular}{|c|c|c|c|}
\hline \multirow[t]{2}{*}{ Parameter name } & \multicolumn{2}{|c|}{$\begin{array}{c}\text { Existing lines which comply with } \\
\text { infrastructure requirements and lines to be } \\
\text { upgraded or reconstructed }\end{array}$} & \multirow[t]{2}{*}{ New lines } \\
\hline & Current indicators & Target indicators & \\
\hline Number of tracks & Not stated & Not stated & 2 \\
\hline Loading gauge & $\mathrm{UIC}^{\mathrm{B} 2)}$ & $\mathrm{UIC}^{\mathrm{B} 2)}$ & $\mathrm{UIC} \mathrm{C2}$ ) \\
\hline $\begin{array}{l}\text { Minimum distance } \\
\text { between track centres }{ }^{1)}\end{array}$ & $4,0 \mathrm{~m}$ & $4,0 \mathrm{~m}$ & $4,2 \mathrm{~m}$ \\
\hline Nominal minimum speed & $100 \mathrm{~km} / \mathrm{h} 3^{\prime}$ & $120 \mathrm{~km} / \mathrm{h} 3^{\prime}$ & $\left.120 \mathrm{~km} / \mathrm{h}^{\prime}\right)$ \\
\hline $\begin{array}{l}\text { Permissible axle load: } \\
\text { - wagons } 100 \mathrm{~km} / \mathrm{h} \\
\text { - } 120 \mathrm{~km} / \mathrm{h}\end{array}$ & $\begin{array}{l}20,0 \mathrm{t} \\
20,0 \mathrm{t}\end{array}$ & $\begin{array}{l}22,5 \mathrm{t} \\
20,0 \mathrm{t}\end{array}$ & $\begin{array}{l}22,5 \mathrm{t} \\
20,0 \mathrm{t}\end{array}$ \\
\hline Maximum gradient ${ }^{1)}$ & Not stated & Not stated & $12,5 \mathrm{~mm} / \mathrm{m}$ \\
\hline $\begin{array}{l}\text { Minimum useful length of } \\
\text { pass-by tracks }\end{array}$ & $600 \mathrm{~m}$ & $750 \mathrm{~m}$ & $750 \mathrm{~m}$ \\
\hline
\end{tabular}

(T) Not particularly relevant for combined transport, but recommended for efficient international combined transport; ${ }^{(2)}$ Own name of gauge; $\left({ }^{3)}\right.$ Minimum train characteristics for combined transport. Source: Own calculations based on[38].

Efficient traffic control on cargo fronts is ensured by the track system of the intermodal terminal. There shall be adequate track links between the different track groups and the overall system shall be designed in accordance with the relevant guidelines and meet all conditions for safe operation. The connection of the terminal with the public road network is achieved through a road system that additionally enables manoeuvring of road vehicles at the terminal, depending on the vehicle handling technology. The road system of the intermodal terminal includes road sections, internal communication and manoeuvring roads and access roads[8].

The storage of intermodal loading and unloading units, both arriving at and departing from the terminal for rail transport, takes place at storage and handling yards. In addition, yards enable the sorting and ordering of intermodal loading units, including those passing through the terminal in transit with transhipment. Storage and handling yards should be designed taking into account the terminal's technological solutions and the type of cargo units to be stored and their susceptibility. It is best to have storage yards within the reach of the main loading bay, as this reduces the number of loading operations to the minimum necessary. Where the necessary storage capacity is greater than the storage capacity within the reach of the main transhipment facility, additional auxiliary storage areas must be created outside the reach of the main transhipment facility [8].

Parking and delivery yards with suitably prepared surface are designed for intermodal loading units that do not require special handling equipment, e.g. road vehicles and semitrailers. These units can be moved in the Rollende Landstrasse and Piggyback systems. The parking of truck-tractors and articulated sets, ordinary and self-loading container semi-trailers, semi-trailers constituting an intermodal loading unit as well as trans-shipment machines and equipment takes place in parking lots located at the terminal. Parking lots should be designed in accordance with the requirements for internal roads and squares[8], [9], [20], [31]. 
The service of train sets with intermodal cargo units takes place on cargo fronts, while the service of road vehicles takes place on cargo fronts and delivery yards. The front and back yards form a cargo system, which is the most important element of an intermodal terminal. The loading system enables the basic terminal function, which is the reloading of intermodal loading units, to be carried out. The technology of handling at the terminal of intermodal loading units determines the way of using particular elements of the loading system[8], [9], [11].

\section{Selected intermodal transport technologies and their comparison}

The implementation of intermodal transport with the use of specific transport systems conditioned by the type of intermodal transport unit requires the use of specific transport technologies. Among the most common transport systems is the container transport system used for the transport of large containers. Transport of semi-trailers and segmental pledges and trucks can be performed with the use of LOHR, Flexiwaggon, CargoSpeed, Megaswing and CargoBeamer systems, where LOHR and CargoBeamer is the manufacturer's own name, while Flexiwaggon, CargoSpeed and Megaswing is the name of the technical system.

Container transport system[8], [11] set of technical means and organizational and legal solutions, used to realize the process of transporting cargo in large containers (Fig. 2). A set of technical equipment of the container transport system consists of [8], [11][20], [27], [31]

- large containers of a unified series of dimensions and maximum gross weights specified in standards or standardization recommendations - ISO[19]

- specialized transport fleet of various modes of transport, including railway platforms, semi-container semi-container trailers, container ships and semi-container ships, as well as inland barges,

- specialized trans-shipment equipment at the interfaces between different modes of transport - in intermodal transport terminals,

- short-range handling aids,

- specialized permanent port and land-based facilities. 

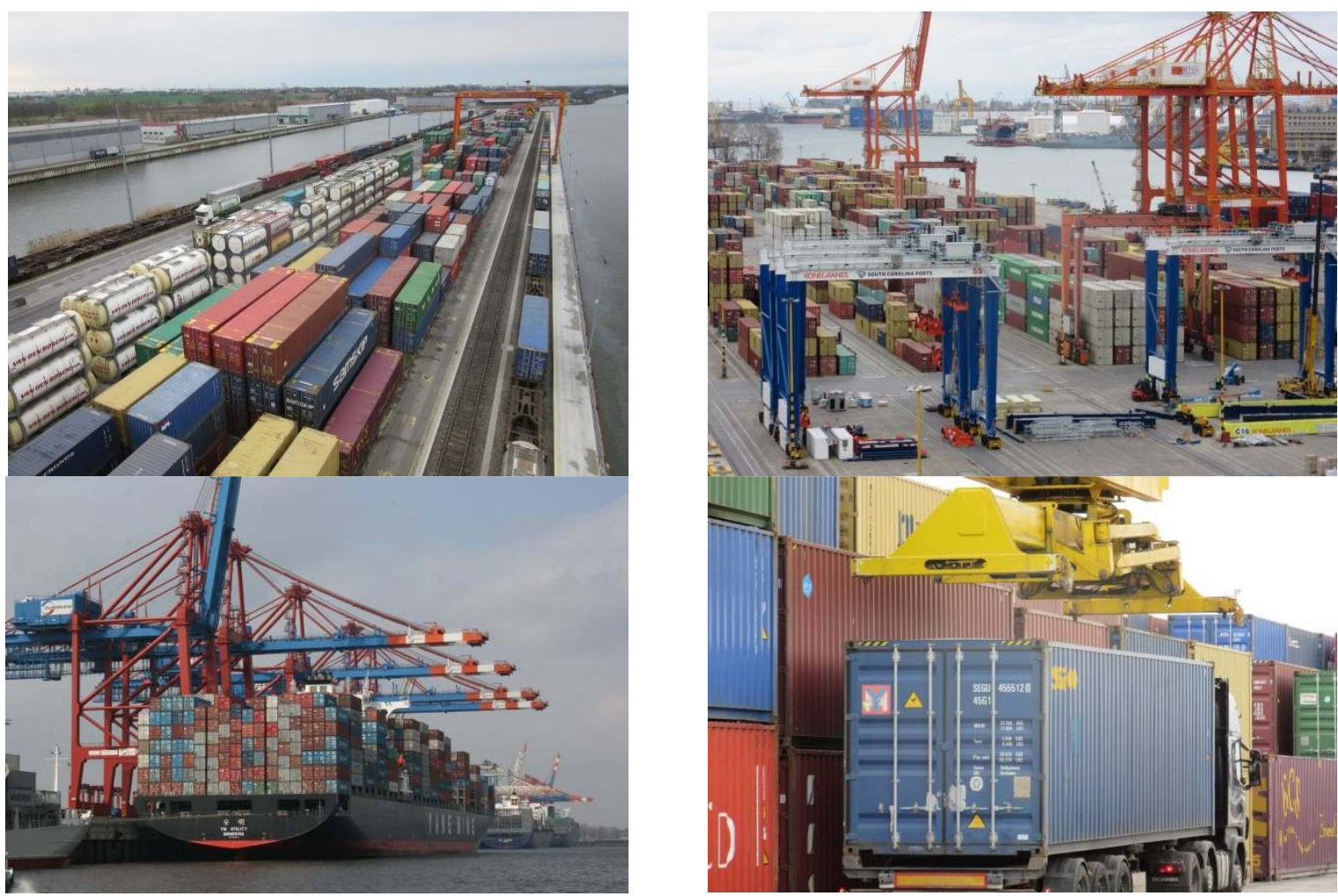

2. Container transport system (Silesian logistics centre, Intermodal Terminal DCT Gdynia and the port of Hamburg). Source: author's own study

The LOHR railway system is used for road-rail transport (piggyback). This technology transports standard semi-trailers safely and efficiently. Semi-trailers are loaded in a horizontal loading system, using a tractor unit, which means that the terminal does not require additional equipment with transhipment equipment. LOHR UIC wagons are pocket wagons equipped with a rotating platform, allowing the transport of semi-trailers with a height of $4 \mathrm{~m}$ on the main European railway lines with a minimum width of UIC GB1[35]. The system uses three types of LOHR UIC wagons with different technical parameters (tab. 2). 
Tab. 2. Technical parameters of LOHR UIC wagons

\begin{tabular}{|c|c|c|c|}
\hline \multirow{2}{*}{ Parameter } & \multicolumn{3}{|c|}{ Parameter characteristics } \\
\hline & UIC 1 & UIC 2 & UIC 3 \\
\hline Connector type 1 & $\begin{array}{l}\text { Standard coupling to } \\
\text { buffers }\end{array}$ & Coupling strap & $\begin{array}{l}\text { Standard coupling to } \\
\text { buffers }\end{array}$ \\
\hline Connector type 2 & Coupling strap & Coupling strap & $\begin{array}{l}\text { Standard coupling to } \\
\text { buffers }\end{array}$ \\
\hline Total length & $33,87 \mathrm{~m}$ & $32,94 \mathrm{~m}$ & $34,80 \mathrm{~m}$ \\
\hline $\begin{array}{l}\text { Load capacity of the } \\
\text { wagon }\end{array}$ & $41,7 \mathrm{t}$ & $40,7 \mathrm{t}$ & $42,7 \mathrm{t}$ \\
\hline $\begin{array}{l}\text { Weight of wagon from } \\
\text { cargo }\end{array}$ & $75,3 \mathrm{t}$ & $76,3 \mathrm{t}$ & $77,3 \mathrm{t}$ \\
\hline $\begin{array}{l}\text { Maximum load of a } \\
\text { semi-trailer }\end{array}$ & \multicolumn{3}{|c|}{$38 \mathrm{t}$} \\
\hline $\begin{array}{l}\text { Minimum turning } \\
\text { radius }\end{array}$ & \multicolumn{3}{|c|}{$135 \mathrm{~m}$} \\
\hline Gauge & \multicolumn{3}{|c|}{ UIC 505-1 - GIC2 (EN 15273-1) } \\
\hline $\begin{array}{l}\text { Maximum floor height } \\
\text { per rail head }\end{array}$ & \multicolumn{3}{|c|}{$225 \mathrm{~mm}$} \\
\hline $\begin{array}{l}\text { Wheel diameter of the } \\
\text { trolleys }\end{array}$ & \multicolumn{3}{|c|}{ Y 25(central) - 0,92 m/Y 33 (extreme) - 0,84 m } \\
\hline
\end{tabular}

Source: Own calculations based on[35].

Due to the technology and the fact that standard semi-trailers can be loaded horizontally, LOHR UIC wagons require special terminals equipped with hydraulic ground systems that enable separation of the central part of the wagon from the bogie modules and rotation to allow the introduction of the semi-trailer (Fig. 3). One system per wagon is being designed at the terminal. LOHR UIC wagons are designed for speeds of $120 \mathrm{~km} / \mathrm{h}$.
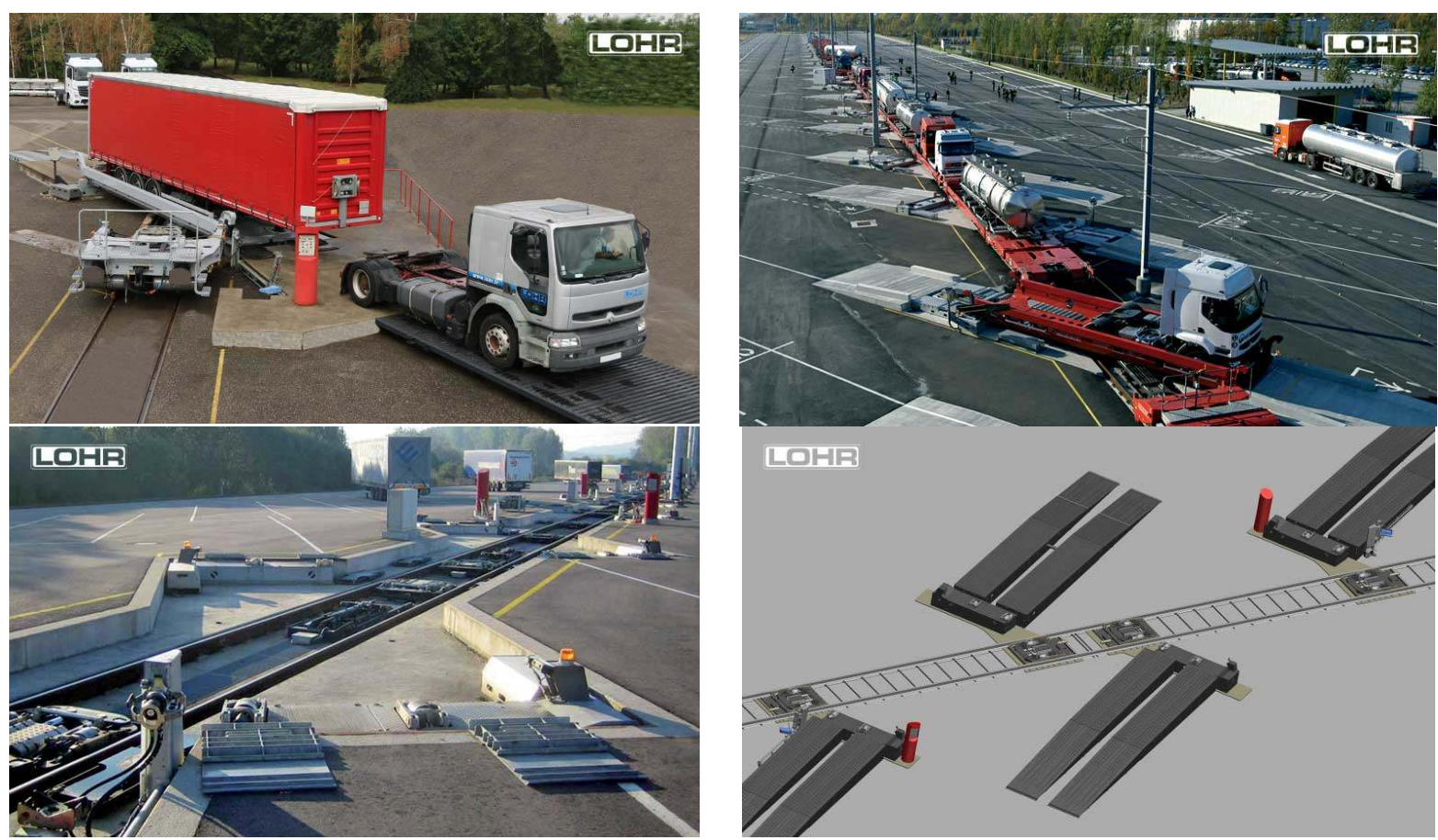

3. The LOHR railway system. Source: LOHR manufacturer's materials[35] 
The LOHR railway system is served by four intermodal terminals located in AitonFrance, Orbassano-Italy (2003) and Bettembourg-Luxembourg, Perpignan-France (2007). The system operates on two routes: the alpine motorway Aiton and Orbassano, $175 \mathrm{~km}$ long, and the motorway Bettembourg and Perpignan, $1000 \mathrm{~km}$ long.

The Flexiwaggon system enables the transport of $18.75 \mathrm{~m}$ long segmented sets and their loading in a horizontal Ro-Ro system. The system consists of special wagons with a rotating platform, additionally equipped with a system of movable supports and actuators moving the overrun ramp of the wagon and stabilizing supports used during loading works, which allows to operate the wagons in places not requiring special preparation (fig. 4). The maximum load weight that can be transported on a Flexiwaggon wagon is 48.4 tons. It takes $10 \div 15$ minutes to turn the platform to load, to drive in or out of the vehicle and to turn the platform to transport. These activities are carried out by the driver of the modular system. Due to the normal wheel diameter of the trolleys $(0.92 \mathrm{~m})$ - the wagons in the Flexiwaggon system are adapted to the speed of $160 \mathrm{~km} / \mathrm{h}[36]$.
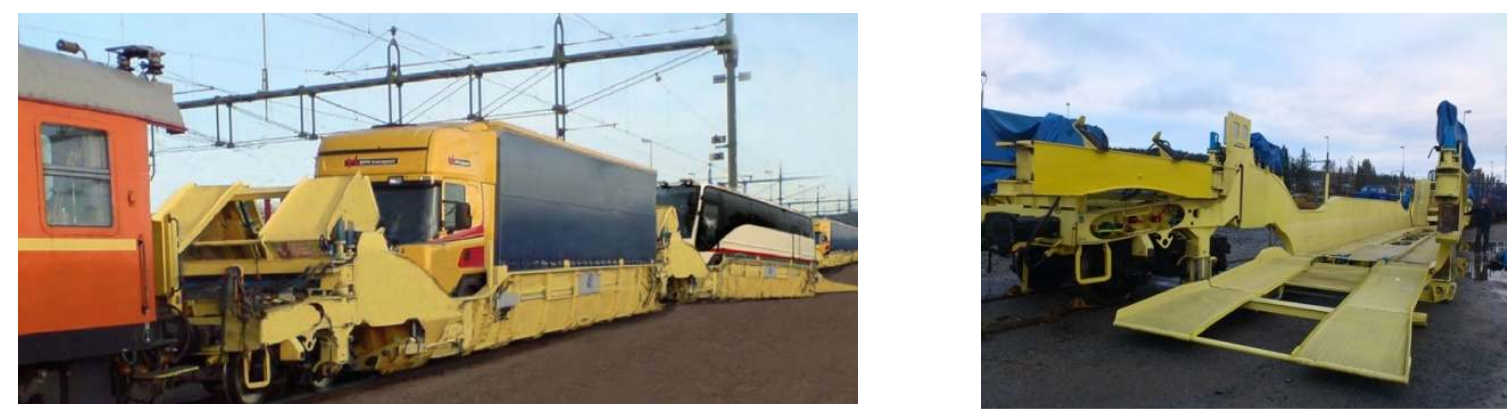

4. The Flexiwaggon railway system. Source: [36]

Each wagon can be serviced individually, which enables the wagon to be serviced in any place. Moreover, the wagons are equipped with electric sockets 110/240/400 V and 50-60 $\mathrm{Hz}$, for cooling devices or for engine heaters of the vehicle.

Flexiwaggon system is equipped with TCS (Train Control System), which through a receiver located in the locomotive allows the receipt of information from the WSC (Waggon Control System) monitoring the operation of the wagon, wheel bearings, deviations in the braking system and other aspects of the wagon. With TCS, a driver can control loading and unloading on one, many or all of the wagons in a train set at the same time[36].

The CargoSpeed system is used to transport semi-trailers. The system is equipped with special pocket wagons with a rotating platform, which enables the segmental sets to be driven on special ramps (fig. 5).
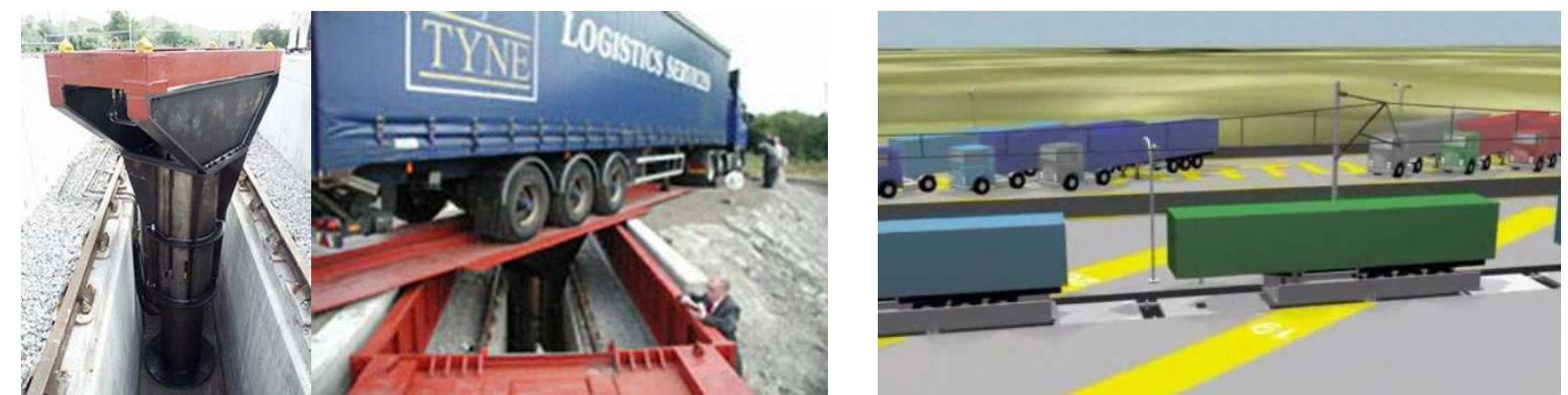

5. The CargoSpeed system. Source: [32]

The wagons are operated on specially prepared terminals equipped with lifts located in the manhole in the track line, which enable lifting and turning the rotating platform. It shall be 
rotated about the vertical centre of the mechanism either $36^{\circ}$ counter clockwise or $144^{\circ}$ clockwise, depending on the train's direction of entry to the terminal. On the terminal, a system of this type is mounted one per wagon. The maximum cargo weight that can be transported on a CargoSpeed wagon is 38.5 tons. The wagons are designed for speeds of 120 $\mathrm{km} / \mathrm{h}[32]$.

The Megaswing system is used to transport semi-trailers or shorter trucks. The system uses two types of wagons, single 4-axle and double 6-axle. A single wagon built of one section based on two extreme carriages. The double carriage is made up of two modules based on two extremities and one central bogie, which is common to both modules [34] (tab. 3).

Tab. 3. Technical parameters of the Megaswing system wagons

\begin{tabular}{|l|l|l|}
\hline \multirow{2}{*}{ Parameter } & Type of wagon \\
\cline { 2 - 3 } & Single 4-axis & Double 6-axis \\
\hline Length with buffers & $19480 \mathrm{~mm}$ & 34030 \\
\hline Distance between bogie pivots & $14750 \mathrm{~mm}$ & $2 \times 14200 \mathrm{~mm}$ \\
\hline Pocket height from rail head & $270 \mathrm{~mm}$ & $270 \mathrm{~mm}$ \\
\hline Width & $2714 \mathrm{~mm}$ & $2714 \mathrm{~mm}$ \\
\hline Wheel diameter & $920 \mathrm{~mm}$ & $920 \mathrm{~mm}$ \\
\hline Own weight & $23,8 \mathrm{t}$ & $38 \mathrm{t}$ \\
\hline Max. axle load of a wheel set & $22,5 \mathrm{t}$ & $22,5 \mathrm{t}$ \\
\hline Max. weight of wagon & $66,2 \mathrm{t}$ & $97 \mathrm{t}$ \\
\hline Max. speed & $120 \mathrm{~km} / \mathrm{h}$ & $120 \mathrm{~km} / \mathrm{h}$ \\
\hline Min. radius of arc & $75 \mathrm{~mm}$ & $75 \mathrm{~mm}$ \\
\hline Gauge & $\mathrm{G} 1$ & $\mathrm{G} 1$ \\
\hline
\end{tabular}

Source: Own calculations based on Kockums Industrier materials.

The Megaswing trolleys are of standard construction, which enables them to be transported in a load condition at a speed of $120 \mathrm{~km} / \mathrm{h}$. Megaswing system units are equipped with sideways swivelling and ramp-down cargo parts. The wagon has its own hydraulic drive of the load platform mechanisms, which does not require additional terminal equipment. Loading is carried out by rear-loading the semi-trailer from a hardened side or ramp from the rail head. When the tractor is uncoupled, the load compartment with the trailer moves into the transport position (Fig. 6).
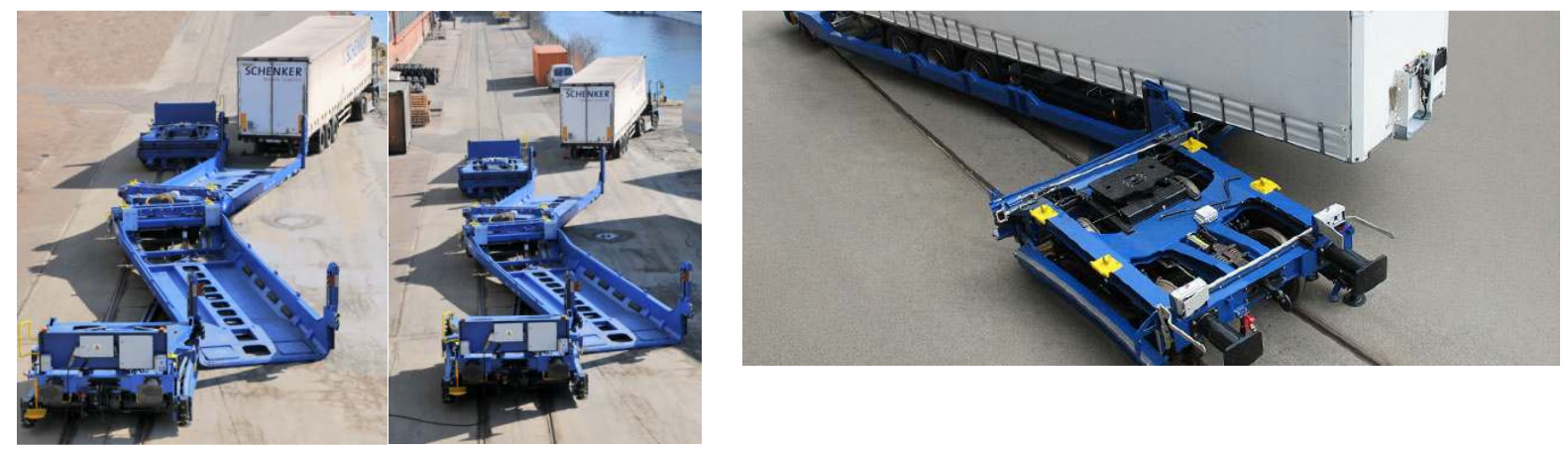

6. The Megaswing system. Source: [34]

The maximum cargo weight to be carried on the wagon in the Megaswing system is 43.0 tons. The system enables unloading of a single wagon in coupled trains, the time of unloading / loading of the whole train set is $30 \mathrm{~min}$. and the time of unloading / loading of a single wagon is $3 \min [34]$ 
The CargoBeamer system is designed for the transport of semi-trailers. It consists of terminals built of trans-shipment modules and wagons with mobile platforms. Trans-shipment modules are made of prefabricated concrete elements armed with rails and devices, which enables the construction of a terminal of any size and a functional and spatial arrangement adjusted to the load capacity. The loading and unloading module with rails, parking tracks for platforms and lorry lanes on each side is $22 \mathrm{~m}$ wide and $19.3 \mathrm{~m}$ long (Figure 7).
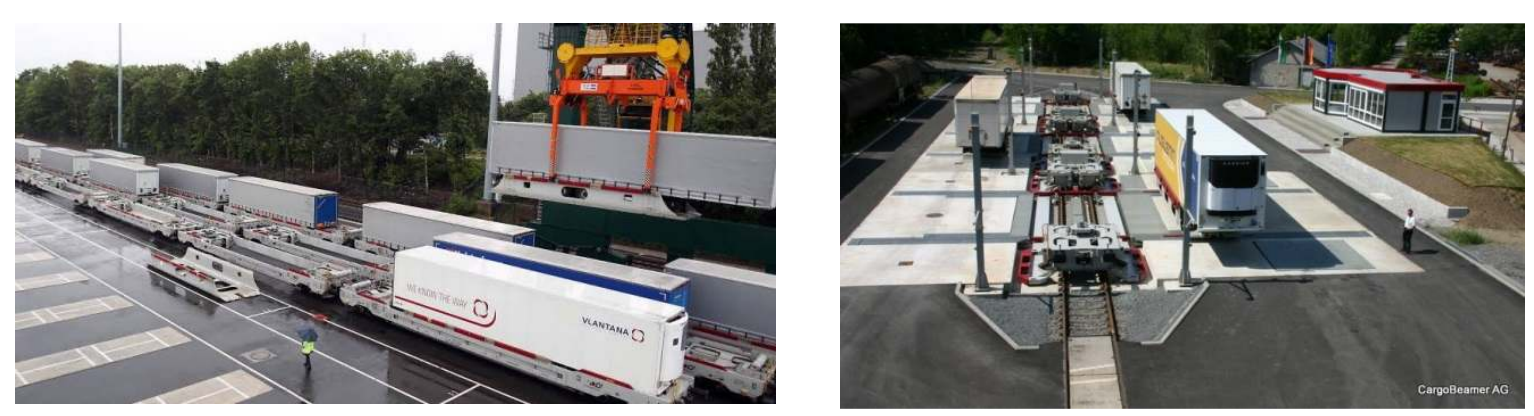

7. CargoBeamer System. Source: [33]

CargoBeamer wagons are equipped with shock absorber buffers type $1 \mathrm{~g}$ from Schwab VT in Schaffhausen (Switzerland), which absorb the acceleration of the trailer even in the event of heavy overrun impacts - an important prerequisite for the transport of sensitive goods. Due to the fact that the wagons have two identical standard Y25 bogies and not Jacobs bogies, the axle loads do not exceed $20 \mathrm{t}$, so that trailers weighing up to $37 \mathrm{t}$ can be loaded on them. The wagons meet the requirements of the gauge according to UIC 505-1 and have a UIC 596-6 compliant pivot spacing of $14200 \mathrm{~mm}$. The side walls of the wagons can be lowered downwards to allow the platform with the trailer to be inserted into the wagon. After the walls have been lifted, they provide protection for the platform and its trailer. CargoBeamer wagons are designed to work with platforms with crane handles for crane or reach-stacker loading. The total length of a buffer wagon is $19,3 \mathrm{~m}$, the axle load with a loaded wagon (semi-trailer $37 \mathrm{t}$ ) less than $19 \mathrm{t}$. CargoBeamer wagons are designed for speeds of up to $120 \mathrm{~km} / \mathrm{h}$. [33]

Movement of platforms is realized by devices installed in terminal modules. The platforms are reloaded fully automatically on all wagons of the train within 15 minutes at the same time. The first experimental terminal was built in Leipzig, the next one in Wolfsburg. The wagons have been granted a permit to operate in several European countries. The CargoBeamer system is planned to be introduced in transit between the Netherlands and Lithuania[33].

Intermodal transport systems determine the range of technical and technological solutions of trans-shipment terminals, as well as the outlays and costs of its maintenance. The comparison of selected technical and cost parameters of the analysed intermodal transport systems is presented in Table 4. 
Tab. 4. Comparison of selected intermodal transport systems

\begin{tabular}{|c|c|c|c|c|c|}
\hline Parameter & FlexiWaggon & Modalohr & CargoBeamer & CargoSpeed & Megaswing \\
\hline \multicolumn{6}{|c|}{ Technical parameters } \\
\hline $\begin{array}{l}\text { Length of wagon } \\
\text { [m] }\end{array}$ & 34 & $\begin{array}{c}33,87 / 32,9 \\
4 / 34,8\end{array}$ & 19,3 & 18,2 & $19,4 / 34,03$ \\
\hline Max. speed $[\mathrm{km} / \mathrm{h}]$ & 160 & $120 / 140$ & 120 & 120 & 120 \\
\hline $\begin{array}{l}\text { Train composition } \\
\text { handling time [min] }\end{array}$ & $\begin{array}{c}10-15 \\
\text { (7 min per } \\
\text { unit) }\end{array}$ & $\begin{array}{c}256 \\
\text { (4 min per } \\
\text { unit) }\end{array}$ & $\begin{array}{c}15 \\
\text { (26 vessels } \\
\text { with } 13 \\
\text { transhipment } \\
\text { systems) }\end{array}$ & 30 & $\begin{array}{c}30 \\
\text { (loading of } \\
\text { the whole } \\
\text { warehouse, } \\
\text { operation of } \\
\text { one unit } 3 \\
\text { min) }\end{array}$ \\
\hline $\begin{array}{l}\text { Load capacity of } \\
\text { wagon [t] }\end{array}$ & 48,4 & $\begin{array}{c}41,7 / 40,7 / \\
42,7\end{array}$ & 37 & 38,5 & 43 \\
\hline $\begin{array}{l}\text { Load length of } \\
\text { wagon/maximum } \\
\text { length of semi- } \\
\text { trailer [m] }\end{array}$ & 18,75 & 13,7 & 14,2 & 16,3 & 14,7 \\
\hline $\begin{array}{l}\text { Special terminal } \\
\text { requirements }\end{array}$ & $\begin{array}{l}\text { No } \\
\text { (necessary } \\
\text { space to } \\
\text { handle the } \\
120 \mathrm{~m}^{2} \text { unit) }\end{array}$ & $\begin{array}{c}\text { Yes } \\
\text { (system } \\
\text { modules } \\
\text { and space } \\
\text { averaging } \\
156 \mathrm{~m} 2 \\
\text { per } \\
\text { module) }\end{array}$ & $\begin{array}{c}\text { Yes } \\
\text { (system } \\
\text { modules and } \\
\text { an average } \\
\text { space of } 117 \mathrm{~m}^{2} \\
\text { per module, } \\
\text { module width } \\
22 \text { m on each } \\
\text { side and length } \\
19.3 \mathrm{~m} \text { ) }\end{array}$ & $\begin{array}{c}\text { Yes } \\
\text { (system/lift } \\
\text { modules and } \\
\text { an average } \\
\text { space of } \\
130 \mathrm{~m}^{2} \text { per } \\
\text { module) }\end{array}$ & $\begin{array}{c}\text { No } \\
\text { (necessary } \\
\text { space to } \\
\text { handle the } \\
120 \mathrm{~m}^{2} \text { unit) }\end{array}$ \\
\hline $\begin{array}{l}\text { Loading under } \\
\text { traction }\end{array}$ & Yes & Yes & Yes & No & Yes \\
\hline \multicolumn{6}{|c|}{ Cost parameters } \\
\hline $\begin{array}{l}\text { Service cost per } \\
\text { transport unit [EUR] }\end{array}$ & 80 & 80 & 75 & $\begin{array}{c}\text { No data } \\
\text { available }\end{array}$ & $\begin{array}{c}\text { No data } \\
\text { available }\end{array}$ \\
\hline $\begin{array}{l}\text { Cost per terminal } \\
\text { location [EUR] }\end{array}$ & $\begin{array}{c}\text { No data } \\
\text { available }\end{array}$ & 74000 & 67000 & $\begin{array}{l}\text { No data } \\
\text { available }\end{array}$ & $\begin{array}{l}30000 \\
\text { (wagon } \\
\text { fittings) }\end{array}$ \\
\hline $\begin{array}{l}\text { Cost of wagon } \\
\text { [EUR] }\end{array}$ & 330000 & $\begin{array}{l}385000 \\
\text { (wagon for } \\
2 \text { loading } \\
\text { units) }\end{array}$ & $\begin{array}{c}360000 \\
\text { (additional } \\
40,000 € \\
\text { wagon base - } \\
\text { pallets) }\end{array}$ & $\begin{array}{l}180000 \\
\text { (double } \\
\text { pocket for } 2 \\
\text { places) }\end{array}$ & 300000 \\
\hline $\begin{array}{l}\text { Cost of } \\
\text { transhipment } \\
\text { infrastructure [EUR] }\end{array}$ & $\begin{array}{l}\text { No data } \\
\text { available }\end{array}$ & $\begin{array}{l}7.7 \text { million } \\
\text { (to page) }\end{array}$ & $\begin{array}{l}\text { 10-20 million } \\
\text { (to page) }\end{array}$ & $\begin{array}{l}\text { No data } \\
\text { available }\end{array}$ & 30000 \\
\hline
\end{tabular}

Source: Own calculations based on[33], [32], [35], [34], [36], [12], [16]

Systems that do not require additional terminal equipment are FlexiWaggon and Megaswing, which require only space to handle intermodal units. Other Modalohr, CargoBeamer and CargoSpeed systems require special terminal equipment, which determines both the time and effort required to build them. The time of unit handling at the terminal is conditioned by the specificity of the transport system, analysis shows that the shortest time of 
train composition handling occurs in the CargoBeamer and FlexiWaggon systems, the longest time of handling occurs in the Modalohr system. It should be noted, however, that train composition handling times are conditioned by the organisation of the handling and the size of the involved potential.

Another criterion for assessing intermodal transport systems is the investment costs of individual terminals, which differ significantly from each other and are determined by the specificity of the system. Modalohr and Cargo Beamer systems require significant infrastructure investments and dedicated terminals, which affects the cost of loading infrastructure. It is estimated that these costs for Cargo Beamer and Modalohr system are at the level of 7.7 and 10-20 million PLN. In addition, the systems require investments in the purchase of specialized railway wagons, which range from PLN 180,000 for the CargoSpeed system to PLN 385,000 for the Modalohr system. In many cases, there is a lack of information in relation to cost parameters or they are very diverse, making it very difficult to compare systems and assess them.

\section{Summary}

The transport of goods in transport systems requires a skilful shaping of the transport network with regard to the interaction of transport modes between different modes of transport. The interaction of modes of transport in the transport of goods consists in changing the mode of transport without the need to reload the goods themselves. Transhipment points such as intermodal transport terminals or logistic centres with appropriate infrastructure play an important role in this respect.

Intermodal transport integrates different modes of transport and combines their strengths, thus creating synergies in terms of increased efficiency and reduced external costs of transport. Technological progress in the construction of means of transport and the organization of transport determines the development of transport technologies in intermodal transport. This requires the construction of specialised facilities - intermodal reloading terminals, where intermodal units are reloaded between means of transport of different modes of transport. In addition, these facilities require specialised equipment adapted to the transport technology used.

Although, in many cases, there is no clear information on the technical and cost parameters for individual terminal solutions, it should be concluded that these systems need to be developed and promoted. The development of intermodal transport systems has a positive impact on the environment, which is a priority in the European Union's transport policy.

Managing freight flow processes in an efficient way and using intermodal transport and rail-road transport in this aspect requires the construction of modern intermodal transport network structures, which require considerable investment. The development of intermodal transport networks is possible thanks to the European Union, which very strongly promotes intermodal transport within the framework of a policy of sustainable transport development. The funds may be obtained within the framework of the Operational Programme Infrastructure and Environment 2014-2020, they are dedicated to the construction, expansion or repair of railway or maritime container terminal infrastructure and logistics centres, as well as the purchase or repair of terminal/centre equipment, systems and equipment, purchase or repair of intermodal rolling stock[37]. These activities may also contribute to the development of transport technologies with the close cooperation of entrepreneurs and scientific institutions involved in such research. 


\section{Source materials}

[1] Ambroziak T., Pyza D., Merkisz-Guranowska A., Jachimowski R., Assessment of the impact of road transport on environmental degradation at different vehicle structures. Publishing House of the Warsaw University of Technology, Warsaw 2014.

[2] Basiewicz T., Gołaszewski A., Rudziński L., Transport Infrastructure. Wydawnicza Oficyna Wydawnicza PW, Warsaw 1998

[3] Beim M., Mazur B., Soczowka A., Zajdler R.: Intermodal transport in Wielkopolska in the light of stakeholder surveys. Communication review no. 6/2016, pp. 25-30. Wrocław 2016.

[4] Beim M., Mazur B., Soczowka A., Zajdler R.: Intermodal transport in Wielkopolskie Voivodeship in the years 2004-2014. Changes, current state and prospects for development. Expert opinion commissioned by the Wielkopolska Regional Territorial Observatory. Poznań 2015.

[5] Bogdanowicz S., Susceptibility. Theory and Application in Transport, Warsaw University of Technology, Publishing House, Warsaw 2012.

[6] Economic Commission for Europe UN/ECE, European Conference of Ministers of Transport (ECMT) and the European Commission (EC): Terminology on combined transport. United Nations New York and Geneva, 2001.

[7] Jacyna M. (ed.), Polish Logistics System. Technical and technological conditions of transport comodality, Publishing House of Warsaw University of Technology, Warsaw 2012.

[8] Jacyna M., Pyza D., Jachimowski R. Intermodal transport. Design of intermodal terminals. Wydawnictwo Naukowe PWN, Warsaw 2017.

[9] Jacyna M., Pyza D.: The role of intermodal transhipment terminals in rail-road transport, Railway Problems. Publishing House of Warsaw University of Technology, Volume 59 Zeszyt 169/2016, pp. 15-27 Warsaw 2016.

[10]Jacyna M.: Multicriteria Evaluation of Traffic Flow Distribution in a Multimodal Transport Corridor, Taking into Account Logistics Base Service. Archives of Transport, Polish Academy of Sciences, Com. of Transport, vol. 10 iss. 1-2, Warsaw 1999.

[11] Jakubowski L., Technology of loading work, Publishing House of the Warsaw University of Technology, Warsaw 2003

[12]Klemenčič M., Burg R.: Data base and comparative analysis of CT and transhipment technologies for CT. Prepared by: University of Maribor, SSP Consult. AlpinnoCT Coordinator 2018.

[13] Communication from the Commission to the Council, the European Parliament, the European Economic and Social Committee and the Committee of the Regions, Freight Transport Logistics in Europe - the key to sustainable mobility, Brussels 2006.

[14] Mindur L., Krzyżaniak S. (ed.): Creating conditions for the functioning and development of the intermodal logistics network of Poland. Institute of Logistics and Warehousing, Poznań 2011.

[15] Mindur L., Transport Technologies, Wydawnictwo Naukowe Instytutu Technologii Eksploatacji - Państwowy Instytut Badawczy, Warszawa-Radom 2014.

[16] New developments in the field of combined transport in UNECE member countries Transmitted by Modalohr, France. Economic Commission for Europe Inland Transport Committee Working Party on Combined Transport 2003.

[17] Ochociński K., Kruk R.: Extra-ordinary railway transports in Poland. Problemy Kolejnictwa - Zeszyt 176/2017, pp. 33-39. Wydawnictwo Instytutu Kolejnictwa. Warsaw 2017. 
[18]Roadmap to a Single European Transport Area - Towards a competitive and resource efficient transport system, White Paper, European Commission, Brussels 2011, $\operatorname{COM}(2011)$.

[19]PN ISO 668:2018-05 - English version - Series 1 cargo containers - Classification, dimensions and maximum gross weight.

[20] Poliński J.: The role of the railway in intermodal transport. Publishing House of the Warsaw University of Technology, Warsaw 2015.

[21] Pyza D., Jachimowski R.: Modelling of Parcels Transport System. Proceedings of 19th International Scientific Conference. Transport Means 2015, Kaunas University of Technology, Lithuania, str. 659-664.

[22] Pyza D., Transport systems modeling in hierarchical distribution, International Conference on Industrial Logistics - ICIL 2012 - Conference Proceedings, ISBN 978953-7738-16-7, Publisher Faculty of Mechanical Engineering and Naval Architecture, Zadar Croatia 2012, 293-300

[23] Pyza D.: Point infrastructure of the Polish Logistics System - chapter 3 - substantive editorial office. Jacyna M. (ed.): Poland's logistic system. Technical and technological conditions of transport co-modality, Wydawnictwo Oficyny Wydawnicza Politechnika Warszawskiej, Warsaw 2012.

[24]Pyza D.: Modeling of transport systems in application to design transport service for business entities. Prace Naukowe Transport, z. 85, Oficyna Wydawnicza Politechniki Warszawskiej, Warsaw 2012.

[25]Pyza D.: Multi-Criteria Evaluation of Transportation Systems in Supply Chains. Archives of Transport, Polish Academy of Sciences Committee of Transport, vol. 23, iss. 1, Warsaw 2011.

[26]Pyza D.: Optimization of transport in distribution systems with restrictions on delivery times. Archives of Transport, Polish Academy of Sciences Committee of Transport, vol. 21, iss. 3-4, Warsaw 2009.

[27]Pyza D.: Intermodal transport transhipment points - subchapter 3.7. [W:] Jacyna M. (ed.): Poland's logistic system. Technical and technological conditions of transport co-modality, Wydawnictwo Oficyny Wydawnicza Politechnika Warszawskiej, Warsaw 2012.

[28]Pyza D.: Selected aspects of modeling of conveyance systems at random supply. Archives of Transport, Polish Academy of Sciences Committee of Transport, volume 20, issue 3, ISSN 0866-9546, Warsaw 2008.

[29]Pyza D.: Trans-European Network - subchapter 2.2, Road transport infrastructure subchapter 2.3, Railway transport infrastructure - subchapter 2.4. [W:] Jacyna M. (ed.): Poland's logistic system. Technical and technological conditions of transport co-modality, Wydawnictwo Oficyny Wydawnicza Politechnika Warszawskiej, Warsaw 2012.

[30]Pyza D.: Transport infrastructure of the Logistics System of Poland - chapter 2. (red.): The logistics system of Poland and transport co-modality, Wydawnictwo Oficyny Wydawnicza Politechniki Warszawskiej, Warsaw 2011.

[31] Pyza D.: Intermodal transport - technical-technological, organisational and functional conditions, [in:] Selected issues of applied logistics, volume IV, ed. J. Feliks, AGH University of Science and Technology Publishing House, pp. 168-179, Kraków 2016.

[32] Web site www. cct.se/cct1/cargospeed.html (Title: Cargospeed)

[33] The websitewww.cargobeamer.pl . (Title: CargoBeamer ... höchste Eisenbahn, cargobeamer.eu [EN] Editorial team)

[34] Website www.kockumsindustrier.se/en-us/our-products/productdetail (Title: Kockumsindustrier)

[35] Website www.lohr.fr/lohr-railway-system/the-lohr-uic-wagons/ (Title: The Lohr UIC Wagons | LOHR) 
[36] Web site www.spin-project.eu (Title: spin-project)

[37] Detailed description of the priority axes of the Operational Programme Infrastructure and Environment 2014-2020. Ministry of Investment and Development. Warsaw 2018.

[38] European Agreement on important international combined transport lines and associated facilities (AGTC), done at Geneva on 1 February 1991

[39] Wronka J.: Intermodal/combined transport in the transport policy of Poland. Communication review no. 8/2015, p. 12-17. Wrocław 2015. 